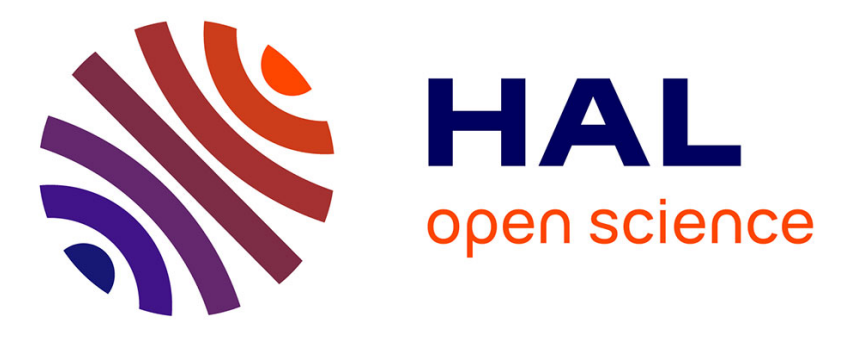

\title{
Travellers and viral haemorrhagic fevers: what are the risks?
}

\author{
Nick J. Beeching, Tom E. Fletcher, David R. Hill, Gail L. Thomson
}

\section{To cite this version:}

Nick J. Beeching, Tom E. Fletcher, David R. Hill, Gail L. Thomson. Travellers and viral haemorrhagic fevers: what are the risks?. International Journal of Antimicrobial Agents, 2010, 36, 10.1016/j.ijantimicag.2010.06.017 . hal-00632726

\section{HAL Id: hal-00632726 \\ https://hal.science/hal-00632726}

Submitted on 15 Oct 2011

HAL is a multi-disciplinary open access archive for the deposit and dissemination of scientific research documents, whether they are published or not. The documents may come from teaching and research institutions in France or abroad, or from public or private research centers.
L'archive ouverte pluridisciplinaire HAL, est destinée au dépôt et à la diffusion de documents scientifiques de niveau recherche, publiés ou non, émanant des établissements d'enseignement et de recherche français ou étrangers, des laboratoires publics ou privés. 


\section{Accepted Manuscript}

Title: Travellers and viral haemorrhagic fevers: what are the risks?

Authors: Nick J. Beeching, Tom E. Fletcher, David R. Hill, Gail L. Thomson

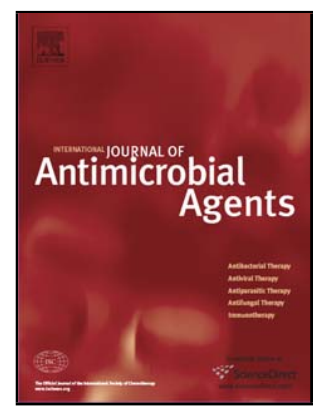

PII: S0924-8579(10)00258-X

DOI: doi:10.1016/j.ijantimicag.2010.06.017

Reference: ANTAGE 3353

To appear in: International Journal of Antimicrobial Agents

Please cite this article as: Beeching NJ, Fletcher TE, Hill DR, Thomson GL, Travellers and viral haemorrhagic fevers: what are the risks?, International Journal of Antimicrobial Agents (2010), doi:10.1016/j.ijantimicag.2010.06.017

This is a PDF file of an unedited manuscript that has been accepted for publication. As a service to our customers we are providing this early version of the manuscript. The manuscript will undergo copyediting, typesetting, and review of the resulting proof before it is published in its final form. Please note that during the production process errors may be discovered which could affect the content, and all legal disclaimers that apply to the journal pertain. 


\section{Travellers and viral haemorrhagic fevers: what are the risks?}

${ }^{*}$ Nick J. Beeching ${ }^{\mathrm{a}, \mathrm{b}}$, Tom E. Fletcher ${ }^{\mathrm{a}}$, David R. Hill ${ }^{c, d}$, Gail L. Thomson ${ }^{\mathrm{a}, \mathrm{e}}$

a Tropical and Infectious Disease Unit, Royal Liverpool University Hospital, Prescot Street, Liverpool L7 8XP, UK

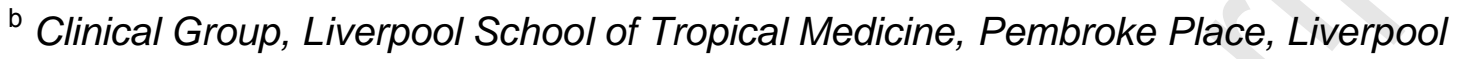
L3 5QA, UK

${ }^{c}$ National Travel Health Network and Centre, UCLH NHS Foundation Trust, 5th Floor West, 250 Euston Road, London NW1 2PG, UK

${ }^{\mathrm{d}}$ London School of Hygiene and Tropical Medicine, Keppel Street, London WC1E 7HT, UK

${ }^{\mathrm{e}}$ Health Protection Agency, Centre for Emergency Preparedness and Response, Porton Down, Salisbury, Wiltshire SP4 OJG, UK

* Corresponding author.

Tel.: +44 (0)151 706 3835; fax: +44 (0)151 7065944 .

E-mail address: nbeeching@blueyonder.co.uk (N. Beeching). 


\section{Abstract}

Viral haemorrhagic fevers (VHF) are caused by zoonotic viral infections transmitted to humans directly or by ticks or mosquitoes. The overall risk to travellers is conservatively estimated at $<1$ in 1 million travel episodes to African countries where infection is present, and febrile patients returning from these countries are at least 1000 times more likely to have malaria than Lassa fever or another VHF. No cases have been reported in fellow travellers exposed to a travelling case and only one asymptomatic seroconversion (to Lassa) has been reported in over 2000 contacts following care of VHF cases in modern Western hospital settings. However, healthcare-associated transmission of infection has been a major problem in some endemic settings. The potential for healthcare-associated infection and the threats posed by unrecognized or new agents necessitate a high index of suspicion and a standardized risk assessment approach to febrile travellers. Travel-related hantavirus infections are increasingly being reported from Europe and the Americas. This article summarizes the epidemiology and reports of travel-related VHF cases in the past 40 years, together with strategies for their recognition, management and prevention.

Keywords:

Travel

Viral haemorrhagic fever

Epidemiology

Risk prevention

Vaccine

Zoonosis 


\section{Introduction}

Viral haemorrhagic fevers (VHF) rarely infect travellers but raise concern because of their potential for a dramatic clinical picture, high mortality, nosocomial transmission and risk to laboratory personnel. Historically, they have been major impediments to military campaigns over the centuries and remain endemic in much of the world, with emerging outbreaks in new locations and recent descriptions of new diseases. In response to travel-related cases of Lassa fever in the USA and the UK, and the importation of Marburg infection into Germany and the former Yugoslavia, proscriptive guidelines for the public health response to imported cases of suspected VHF and their clinical and laboratory management were developed in the 1970s [1]. These have been reinforced in a recent European consensus statement $[2,3]$. Several VHF agents have been weaponized and their continued potential for deliberate release has been emphasized $[2,4,5]$.

The purpose of this review is to focus on the risks of acquiring a VHF during travel and to update lists of known importations of cases across national borders.

Epidemiological and clinical approaches to the management of returned travellers with fever are also discussed. Full clinical descriptions of each infection are beyond the scope of this article but can be accessed from recent reviews. Dengue $[6,7]$ is excluded from this review and only passing mention will be made of the many VHFs that have localized geographical niches and that have not been reported as being travel related.

\section{Methods}

We conducted reviews of the Medline/PubMed databases for the period 1966-2009, the online database Google Scholar and the ProMED database using the keywords 
'travel', 'traveller' and 'imported' combined with the terms 'VHF' and 'viral haemorrhagic fever' and with each of the diseases being described. In addition we reviewed relevant sections of the websites of the US Centers for Disease Control and Protection (www.cdc.gov), Health Canada (www.hc-sc.gc.ca/index-eng.php), the UK Health Protection Agency (www.hpa.org.uk), the English National Travel Health Network and Centre (www.nathnac.org) and the World Health Organization (www.who.int/en). Standard textbooks of infectious diseases and travel medicine were consulted, together with appropriate reviews and recently published books about VHF [8,9] and infections in military settings [10].

We cross-correlated references from these sources, when possible including papers in all languages. We list the source references for each case of VHF reported to have crossed an international boundary and highlight key references for further reading on clinical and epidemiological management. Laboratory-acquired cases have not been tabulated, nor have infections arising as a result of animal importation.

\section{Epidemiology}

\subsection{General features}

The agents causing VHFs are RNA viruses in the families Arenaviridae, Bunyaviridae, Filoviridae and Flaviviridae. All are known or thought to be zoonoses, some associated with very specific hosts, vectors and locations, such as the South American arenaviruses, and some with a larger range of animal hosts and wider intercontinental distribution, such as Crimean-Congo haemorrhagic fever (CCHF). Key epidemiological features of VHFs known to have affected international travellers are summarized in Table 1. 
[Table 1 here]

The routes of transmission of VHF to man in nature can be categorized into three broad groups [11]. The first includes infections that are only transmitted by arthropod vectors, such as yellow fever (YF) and most other flaviviruses, and are not usually spread from person to person. The second group includes agents spread to man by contact with uncooked meat, blood, urine, saliva and other secretions of animals, such as arenaviruses, hantaviruses and filoviruses. Contamination of foodstuffs or human habitation by rodent urine has been implicated in the spread of arenavirus and hantavirus infections, but the zoonotic transmission routes to man of filovirus infections remain less clear (see below). The third group, which includes the bunyaviruses causing CCHF and Rift Valley fever (RVF), may be spread by arthropod vectors or by body-fluid contact.

In general, the human populations at most risk in endemic areas are pastoralists, butchers, slaughterers and others who have close contact with animals, their products and their ticks; people living in housing with peri-domestic rodent infestation; and those with occupations that take them into areas with enzootic transmission, such as mining, engineering, forestry work, cane cutting and agricultural labourers. Traditional funeral practices and close domestic contact can also result in infection in these settings. Civil unrest, conflict and political changes leading to the displacement of populations and breakdown of public health systems have been implicated in epidemics of VHFs such as CCHF and Marburg. Changes in climate conditions leading to increases in rodent hosts favour the spread of hantavirus infections in Europe [12] and epidemics of RVF have followed heavy rains and consequent increases in mosquito vectors in Egypt and Kenya [8]. Similar 
conditions and alterations in land use may also account for some of the recent expansion of CCHF in South and Eastern Europe [13].

\subsection{Infection in endemic settings}

Hospital-associated transmission of infection has been responsible for the amplification of local outbreaks of several VHFs in Africa, including Ebola, Marburg and Lassa. Poor infection control measures and the reuse of sharps has resulted in onward transmission of infection to patients and staff in these settings. Other risks to staff and visitors include close contact and subsequent contamination with body fluids of patients, and mucocutaneous exposure to blood, saliva and respiratory secretions, especially during resuscitation or procedures that create infectious aerosols. This includes splashes of blood and other fluids into the mouth or eyes. Droplet spread of respiratory secretions may also play a small role.

In general, dramatic outbreaks of nosocomial infection within endemic areas have been terminated by the provision of adequate medical supplies and training staff in the proper use of personal protective equipment, together with enforcement of guidance about the safe handling of deceased patients [14]. The risks of contact infection and nosocomial infection in high-income settings are discussed in more detail later in this review. Patients, expatriates and local healthcare staff sent to Europe or the USA for medical care are included in Tables 2 and 3, which list individual cases of VHFs that have travelled internationally.

\subsection{Infections in travellers}

Other travellers whose occupations or leisure activities bring them into contact with settings at risk for VHF are at particular risk; this includes both international travellers and those who do not cross national borders. Camping, hiking and other rural 
holiday pursuits may expose travellers to ticks and mosquitoes or to rodent urine, while occupations such as mining, geological field work and cave exploration can result in contact with animal hosts. Military and peacekeeping personnel on active duty in the field are at risk if they are exposed to rodents, ticks or mosquito vectors. Mass gatherings can increase the risk of any infection, and the annual Hajj pilgrimage is of theoretical concern because it is accompanied by massive importation of animals for slaughter [15].

Lassa fever was the first VHF to be identified in a traveller and is the most common imported VHF, with 28 cases documented in the past 30 years (Table 2). At least nine were healthcare workers in Africa and most of the remainder had rural occupations, including aid workers and military personnel. These infections all occurred in West Africa, especially Nigeria and Sierra Leone, with the first reported case from Mali in 2009. In 2008 a novel Old World arenavirus, Lujo virus, caused the death of a Zambian resident and the paramedic who assisted in her transport to South Africa for medical care [43]. Two nurses who attended the patients in South Africa also became infected, together with a hospital cleaner. Only the nurse who received ribavirin survived. The natural reservoir, geographical range and distribution of subclinical human infection with this new virus have yet to be determined, but the sequence of events is a reminder of the dangers of unrecognized illness due to VHFs.

[Table 2 here]

Only a few cases of imported filovirus infection have been reported. Table 3 includes two patients who travelled within Kenya, illustrating the link between these infections in travellers to cave exploration and bat exposure, in addition to an outbreak of Marburg infection in miners exposed to bats [84]. Fruit bats have now been 
confirmed to carry Marburg and Ebola infections, although the mode of transmission to people has not been determined $[85,86]$. Other large non-human primates can also be infected, and some human filovirus infections have been epidemiologically linked with the local preparation or consumption of non-human primate 'bushmeat'.

[Table 3 here]

Given the large geographical range of CCHF in Africa, Eastern Europe, the Middle East and central Asia as far as Xiang Xiang Province in China, it is surprising that more travel-related infections have not been reported. Most cases have involved proven or possible exposure to ticks, including crushing ticks with unprotected fingers (Table 3). The recent acquisition of a lethal infection by an American serviceman in Afghanistan emphasizes the need to consider CCHF in the differential diagnosis of fever from this area [57].

Similarly, few clinical cases of RVF have been reported in travellers until recently, apart from two cases returning to the West for expert care of ophthalmic complications of infection and a patient in whom RVF may have contributed to death due to acute hepatitis A (Table 3). Subclinical cases have been identified in peacekeeping and military personnel stationed in endemic areas [59,61]. Hantaviruses are found in most continents and caused epidemics of haemorrhagic fever with renal syndrome (HFRS) in civilians and troops during World War I and the Korean War [10]. Recent reports of infected travellers in Europe and Asia again include both military and civilian personnel (Table 3). The European forms of HFRS have been reported in peacekeepers in the Balkan region, and travel-related cases are being reported more often from Western Europe and Scandinavia, especially in campers. The need for reference laboratory testing was emphasized by a recent 
'pseudo-importation' of hantavirus from Ecuador to Belgium, subsequently shown to have been acquired after return to Belgium [80]. In the New World, several new infections leading to hantavirus pulmonary syndrome (HPS) have been recognized, and a few travel-related cases have been reported (Table 3).

Yellow fever (YF) was a major cause of death of early European travellers to West Africa and was taken to the Americas with the slave trade [10]. From the 17 th to the end of the 19th century tens of thousands of British, French, Dutch and Spanish troops were killed by YF outbreaks in the Caribbean and Central American region, and importation of YF to the USA was a constant problem, with onward transmission by local populations of Aedes mosquitoes. Mosquito bite avoidance measures and vaccination have been available for almost a century, but ten imported cases have been reported in the last three decades, usually in tourists who had not been vaccinated (Table 4).

[Table 4 here]

\subsection{Animal travel and VHFs}

Animal movements have been implicated in the spread of CCHF in central Asia [98] and the Arabian peninsula $[99,100]$, of RVF into Saudi Arabia and the Yemen [101] and possibly in the recent emergence of human infections with Alkhurmah virus, a novel flavivirus similar to Kyasanur Forest disease in western Saudi Arabia [102]. The risk of animal importation to the West was exemplified by outbreaks of Marburg disease involving 31 people, including 6 secondary cases, in Frankfurt, Marburg and Belgrade in 1967 [103], traced to monkeys used to provide tissue for cell-culture lines. Asymptomatic seroconversions have occurred in animal handlers looking after macaque monkeys imported from the Philippines, resulting in transmission of a strain 
of Ebola within a primate facility in Reston, Virginia [104], and in pig handlers in the Philippines [105]. Imported rodent cell lines have been the source of hantavirus infections in laboratory workers in the UK [106]. In the past, importation of infected mosquito vectors has been implicated in the transmission of $Y F$, and this should be prevented by spraying aircraft that come from endemic areas [107].

\section{Clinical features}

VHF are severe infections with high mortality rates in travellers (Tables 2-4), apart from Puumala virus forms of HFRS from Europe. Details of clinical features in endemic settings and in travellers are beyond the scope of this review but can be found in textbooks and the references cited. The onset of most infections is abrupt, often with severe malaise and headache in the early stages, sometimes resembling encephalitis. Severe infections often follow a biphasic course, with initial improvement followed by multisystem failure in the second week, including encephalopathy. Haemorrhagic features can be absent at presentation in a substantial minority of patients and are rarely seen in the northern European forms of HFRS, or in patients with HPS or RVF. A fine rash may be seen in the first week of filovirus infections, and pharyngitis and/or facial swelling in patients with Lassa fever. Jaundice can be prominent in YF and RVF. Abdominal pain can be severe in patients with Ebola, Marburg or CCHF, and prostration is a prominent feature of Ebola. Ophthalmic problems can complicate RVF (retinitis) and Lassa (uveitis), which also causes deafness. Spontaneous abortion is a feature of Lassa, Ebola and CCHF.

The differential diagnosis is wide and includes respiratory infections in the early stages, as well as malaria, dengue and other arboviruses, enteric fever, viral hepatitis, leptospirosis, meningococcaemia, encephalitis and rickettsial infections. 
Most infections cause neutropenia, thrombocytopenia, proteinuria and raised transaminases, plus other laboratory abnormalities related to the infecting organism, such as renal failure with hantaviruses causing HFRS. Specific diagnosis largely rests on virus culture or rapid molecular tests; serological methods may help in acute cases, but are mainly useful in convalescence. Such tests should only be performed by prior arrangement with national reference centres [3].

Treatment is largely supportive, including dedicated high-security intensive care [3,5]. Ribavirin (unlicensed for these purposes) has proven beneficial when given early in Lassa fever and is used for other arenavirus infections. It appears to be useful in CCHF in areas were mortality is high, although its role remains controversial [108]. It confers no benefit in filovirus infections.

\section{Risks assessment and management of returned travellers}

\subsection{Healthcare settings}

Risk assessment to inform the management of patients returning from overseas with febrile symptoms should assess the likelihood that their illness is because of VHF, the likelihood of the infection being transmitted to workers, and the seriousness of the outcome of such transmission. The risks of delaying diagnosis and treatment of other treatable infections such as malaria should also be incorporated in the risk assessment process.

Firstly, how common are these infections? The overall risk to travellers is conservatively estimated at $<1$ in 1 million travel episodes to African countries where infection is present. In the recent GeoSentinel review of returned travellers with febrile illness managed in specialist centres around the world, VHF was not diagnosed in 6957 patients, of whom 2559 had returned from sub-Saharan Africa 
[109]. Malaria was the most common diagnosis, as it was in $14 / 23(61 \%)$ of patients specifically screened for VHFs in London in the early 1980s [110] and in $14 / 37$ (38\%) travellers with possible VHF risk more recently at the London Hospital for Tropical Diseases [111]. Africa, especially West and central Africa, has been the origin of most imported cases of VHF but is also the most common origin for severe malaria imported to Europe and North America [109] and there is a remote possibility that a traveller might have both. During the decade $2000-2009$, four patients have imported VHFs to the UK (Tables 2 and 3), compared with 17109 cases of malaria [112], and 4061 cases of enteric fever notified 2000-8 (mostly imported) [113]. More detailed risk assessment of the returned traveller with a febrile illness, especially with a rash, jaundice or haemorrhagic manifestations that cannot otherwise be explained, should take into account the countries visited, the specific areas visited within the country, and activities that might have put them at risk, including rural work and leisure pursuits such as cave visits and mining; contacts with wild animals, especially bats, rodents or their excreta; and working in or attending a health facility as a patient. The incubation period is taken into account, as none of the transmissible VHFs in Africa have an incubation period longer than 21 days. If the onset of symptoms has occurred more than 21 days after leaving an endemic area, the risk of VHF can be excluded [2,111]. Patients at medium or high epidemiological risk should be isolated and discussed with national clinical, laboratory and public health experts. Initial investigations beyond exclusion of malaria should be kept to a minimum. If malaria is excluded, hence increasing the possibility of a VHF causing the illness, the intensity of isolation can be escalated, according to local or national guidelines. 
Although regulations have been in force in the UK since $1976[1,114]$, they are rarely applied systematically, even in specialist units. A travel history is only obtained from about $10 \%$ of patients with fever attending busy emergency rooms in the north-west of England (unpublished audit), and only a minority of patients thought to have potentially transmissible infections are isolated in British emergency rooms [115]. A recent survey of 21 British infectious disease units revealed that written VHF protocols available in six units were only systematically followed in two units; eight others discussed VHF risks in unit guidelines, and seven had no written protocols [111]. One concern voiced by specialists is that use of such protocols might increase the delay in diagnosing falciparum malaria, which can rapidly be fatal and should be treated immediately $[116,117]$. However, an audit of delays in diagnosis made at the London Hospital for Tropical Diseases, where use of the VHF assessment protocol is embedded in daily practice, only showed an increase in time to laboratory diagnosis of malaria from a median 90 min (range 50-125) for patients not thought to be at VHF risk to 140 mins (101-225) for those assessed as having a possible VHF [111]. The next issue is the risk to personnel attending the patient. In a review of contact tracing for nine patients admitted to Western facilities with Lassa fever, no clinical illness was seen in 1521 contacts, including fellow travellers and healthcare workers [118]. One German physician (who had received ribavirin prophylaxis) had an asymptomatic seroconversion after failing to use adequate barrier precautions, yielding an estimated transmission risk of $0.06 \%$ [118]. To this may be added 576 further healthcare contacts screened after recently imported cases of Lassa to the UK, with no secondary cases $[34,41,42]$. No clinical cases were found after surveillance of almost 400 contacts of Marburg [47,48], 74 contacts of Ebola [50] or 245 contacts of CCHF $[53,56]$ in recent travellers. Concern lingers, however, 
because of the theoretical risk of aerosol dispersion of some infections, reinforced by the apparent remote airborne spread of the Ebola-Reston virus to non-human primates, and transmission of asymptomatic infections to animal handlers. Several excellent reviews include further details about healthcare-associated risks and the specific precautions that are necessary to reduce them $[1,3,4,34,118,119,120,121]$. To summarize, a VHF should be considered in a traveller with fever $\geq 38^{\circ} \mathrm{C}$ that starts within 21 days of leaving a risk area, especially if they have any of the risk exposures detailed earlier, and a severe illness with haemorrhagic manifestations, rash or other features, such as jaundice, that are compatible with a VHF and cannot be explained by malaria or other conditions. Such patients should be isolated in a single room, preferably with negative pressure, and attendants and diagnostic sampling kept to a minimum. Healthcare workers should adopt precautions against contact with blood and secretions, including gloves, gowns and eye protection, and against droplet spread of infection. Care should be taken to avoid contamination during removal or safe disposal of personal protective equipment. Suspected cases should be discussed immediately with appropriate local public health personnel and national clinical experts, who will assist with determining the future epidemiological, diagnostic and clinical management of the patient and contacts. This might include transfer to a special isolation facility $[3,34]$.

Although no cases of transmission have been documented as a result of routine diagnostic laboratory processing of specimens from returned travellers, clinical laboratories should be warned that there is a known or potential VHF risk and diagnostic sampling kept to a minimum. The closed systems used in modern clinical haematology and biochemistry laboratories should be safe. Samples should be transported safely and handled in appropriate safety cabinets by adequately trained 
personnel. Apart from risks of direct exposure to blood and other fluids and tissues, there is a potential risk of aerosol dissemination. Specific virological tests should only be performed in designated laboratories by personnel trained to use biosafety level 4 containment facilities. There is a high risk to mortuary personnel and undertakers. All contacts with patients or samples should be identified and categorized according to their exposure risk $[3,34,41,42,111]$.

\subsection{Risks for fellow travellers and family contacts}

Outside endemic areas and settings, fellow travellers have never been known to contract a VHF from another infected traveller. In the past, heroic efforts have been made to trace fellow travellers across international boundaries, such as following the importation of Lassa fever to the USA, with no evidence of transmission in several hundred potential contacts [21]. Within endemic areas, close family contact (excluding the preparation of bodies for burial) has been implicated in the transmission of most VHFs originating in Africa, but this has only been documented in Western settings for Marburg infection transmitted sexually to a female spouse, and in South America for Argentinean haemorrhagic fever [4] and Andes HPS virus [122]. Sexual transmission of other viruses, particularly Lassa, Ebola, CCHF, other arenaviruses and hantaviruses remains undocumented, but both Lassa and Ebola have been detected in semen 3 months after infection [4,8].

\section{Prevention for travellers}

\subsection{General}

Many resources are available to inform travellers about potential health risks at their destination and while travelling. Healthcare workers who plan to work in an area endemic for a VHF should familiarize themselves with local risks and appropriate 
protective measures. Travellers in areas with mosquito-borne VHFs such as YF and RVF should take precautions to reduce the risk of bites, predominantly by Aedes mosquitoes, which are daytime and dusk feeders. This includes wearing longsleeved shirts and long trousers, and using repellents. Tick bites can be minimized by tucking trousers into socks and impregnating clothes with permethrin, and by avoiding direct contact with animals such as sheep, cattle and goats. Travellers potentially exposed to ticks should inspect themselves regularly and remove any attached ticks carefully, avoiding crushing the tick or handling it with unprotected fingers. Ticks are more easily seen on pale-coloured clothing. In Africa, travellers should not handle or eat non-human primate-derived 'bushmeat' and should not handle or consume uncooked meat, blood or secretions (including unpasteurized milk) from animals in CCHF- or RVF-endemic areas.

Campers and others travelling or working in rural areas should avoid contact with rodents or their excreta and should wear masks if it is essential to sweep out habitations infested by rodents in any area where Lassa or other arenaviruses or hantaviruses are prevalent. In light of current knowledge, contact with fruit bats or their habitations, such as caves in Africa, should also be avoided.

\subsection{Immunization}

The only approved vaccine against a VHF in travellers is for YF, although unlicensed or restricted vaccines have been used for RVF and in some areas against HFRS agents. YF vaccination may be required under international health regulations by individual countries as a condition of entry, and/or recommended to prevent acquiring YF. Unfortunately, the information provided by tour companies and travel agents to travellers visiting YF risk areas may not accurately discuss the risk and 
requirements for vaccination. Of the 10 imported cases reported in the last 30 years, only one had been immunized (Table 4).

Although the risk of YF infection in travellers to West Africa has been estimated to be higher than that in travellers to endemic areas of South America [87], 4 of the 10 cases in Table 4 had been to the Americas. Recent expansion of YF transmission in South America, along with the recognition of rare but life-threatening adverse events following YF vaccine, especially in those aged 60 and older [123], emphasize the need to improve the definition of YF risk areas. Geographic mapping of risk based on review of human and non-human primate cases, YF serology, vegetation, altitude and vector distribution has been undertaken by a World Health Organization (WHO) working group. They will harmonize internationally accepted maps of risk areas published by WHO and the Centers for Disease Control and Prevention, with clearer definitions of level of risk and vaccination recommendations down to small geographical zones. These maps should be available by the end of 2010 .

\section{Conclusions}

The risk of a traveller acquiring a VHF is extremely small, but the consequences for them and for those involved in their care are potentially devastating. Patients with an imported VHF often have contact with many healthcare personnel before their diagnosis is recognized, but no clinically significant cases of transmission to healthcare attendants have been recorded in modern Western hospital settings. Nevertheless, it is important to take adequate travel histories from patients with fever and perform a more specific risk assessment for patients returning from areas endemic for a VHF. Management of suspected cases should follow national protocols. Travellers need to be informed about the health risks associated with their travel plans, and to take steps to reduce personal risk. 


\section{Acknowledgment}

We thank Jo Lawrence of the Travel and Migrant Health Section, Centre for Infections, Health Protection Agency, for supplying aggregated data on enteric fever notifications in the UK.

Funding: None.

Competing interests: None declared.

Ethical approval: Not required. 


\section{References}

[1] Galbraith NS, Berrie JRH, Forbes P, Young SEJ. Public health aspects of viral haemorrhagic fever in Britain. J R Soc Health 1978;98:152-61.

[2] Bossi P, Tegnell A, Baka A, van Loock F, Hendriks J, Werner A, et al. Bichat guidelines for the clinical management of haemorrhagic fever viruses and bioterrorism-related haemorrhagic fever viruses. Euro Surveill 2004;9:pii=504. http://www.eurosurveillance.org/ViewArticle.aspx?Articleld=504 [accessed 27 Mar 2010].

[3] Brouqui P, Puro V, Fusco FM, Bannister B, Schilling S, Follin P, et al. Infection control in the management of highly pathogenic infectious diseases: consensus of the European Network of Infectious Disease. Lancet Infect Dis 2009;9:301-11.

[4] Borio L, Inglesby T, Peters CJ, Schmaljohn AL, Hughes JM, Jahrling PB, et al. Hemorrhagic fever viruses as biological weapons: medical and public health management. JAMA 2002;287:2391-405.

[5] Kortpeter MG, Martin JW, Rusnak JM, Cieslak TJ, Warfield KL, Anderson EL, et al. Managing potential laboratory exposure due to Ebola virus by using a patient biocontainment care unit. Emerg Infect Dis 2008;14:881-7.

[6] Wilder-Smith A, Tambyah PA. Severe dengue virus infection in travelers. J Infect Dis 2007;195:1081-3.

[7] Hochedez P, Canestri A, Guihot A, Brichler S, Bricaire F, Caumes E. Management of travelers with fever and exanthema, notably dengue and chikungunya infections. Am J Trop Med Hyg 2008;78:710-3. 
[8] Howard CR. Viral haemorrhagic fevers. In: Zuckerman AJ, Mushahwar IK, editors. Perspectives in medical virology. Amsterdam: Elsevier; 2005.

[9] Ergönul O, Whitehouse CA, editors. Crimean-Congo hemorrhagic fever: A global perspective. Dordrecht, Netherlands: Springer; 2007.

[10] Smallman-Raynor MR, Cliff AD. War epidemics. Oxford: Oxford University Press; 2004.

[11] Solomon T. Viral haemorrhagic fevers. In: Gill GV, Beeching NJ, editors. Lecture notes: Tropical medicine. Oxford: Wiley-Blackwell; 2009, pp. 289-95.

Heyman P, Vaheri A, the ENIVD members. Situation of hantavirus infections and haemorrhagic fever with renal syndrome in European countries as of December 2006. Euro Surveill 2008;13(28):pii=18925.

http://www.eurosurveillance.org/ViewArticle.aspx?Articleld=18925 [accessed 28 Mar 2010].

Maltezou HC, Andonova L, Andraghetti R, Bouloy M, Ergonul O, Jongejan F, et al. Crimean-Congo hemorrhagic fever in Europe: current situation calls for preparedness. Euro Surveill 2010;15(10):pii=19504. http://www.eurosurveillance.org/ViewArticle.aspx?Articleld=19504 [accessed 28 Mar 2010].

CDC and World Health Organization. Infection control for viral haemorrhagic fevers in the African health care setting. Atlanta, GA: Centers for Disease Control and Prevention; 1998.

http://www.cdc.gov/ncidod/dvrd/spb/mnpages/vhfmanual.htm [accessed 28 April 2010]. 

2006;367:1008-15. clinical update. Emerg Infect Dis 2006;12:835-7.

[17] Frame JD, Baldwin JM, Gocke DJ, Troup JM. Lassa fever, a new virus disease of man from West Africa. I. Clinical description and pathological findings. Am J Trop Med Hyg 1970;19:670-6.

[18] Gilles HM, Kent JC. Lassa fever: retrospective diagnosis of two patients seen in Great Britain in 1971. Br Med J 1976;2:1173.

[19] Woodruff AW, Monath TP, Mahmoud AA, Pain AK, Morris CA. Lassa fever in Britain: An imported case. Br Med J 1973;3:616-7.

[20] Vella EE. Lassa fever. Hospital Update 1976;2:31-7.

[21] Zweighaft RM, Fraser DW, Hattwick MA, Winkler WG, Jordan WC, Alter M, et al. Lassa fever: response to an imported case. N Engl J Med 1977;297:803-7.

[22] Department of Health and Social Security. Annual report of the Chief Medical Officer. On the state of the public health for the year 1976. London: HMSO; 1977, pp. 52-4.

[23] World Health Organization. Lassa fever surveillance. Wkly Epidemiol $\operatorname{Rec} 1981 ; 56: 47-8$.

[24] Cooper CB, Gransden WR, Webster M, King M, O'Mahony M, Young S, et al. A case of Lassa fever: experience at St Thomas's Hospital. Br Med J 1982;285:1003-5. 
[25] Public Health Laboratory Service Communicable Disease Centre.

Lassa fever 1982. Br Med J 1983;287:48.

[26] Emond RTD, Weir WR, Bowen ET, Lloyd G, Southee T. Managing Lassa fever. Lancet 1984;2:926.

[27] Fisher-Hoch SP, Price ME, Craven RB, Price FM, Forthall DN, Sasso $\mathrm{DR}$, et al. Safe intensive-care management of a severe case of Lassa fever with simple barrier nursing techniques. Lancet 1985;2:1227-9.

[28] Hirabayashi Y, Oka S, Goto H, Shimada K, Kurata T, Fisher-Hoch SP, et al. An imported case of Lassa fever with late appearance of polyserositis. $J$ Infect Dis 1988;158:872-5.

[29] Schlaeffer F, Bar-Lavie Y, Sikuler E, Alkan M, Keynan A. Evidence against high contagiousness of Lassa fever. Trans R Soc Trop Med Hyg $1988 ; 82: 311$.

[30] Mahdy MS, Chiang W, McLaughlin B, Derksen K, Truxton BH, Neg K. Lassa fever: The first confirmed case imported into Canada. Can Dis Wkly Rep 1989;15:193-8.

Holmes GP, McCormick JB, Trock SC, Chase RA, Lewis SM, Mason CA, et al. Lassa fever in the United States. Investigation of a case and new guidelines for management. N Engl J Med 1990;323:1120-3.

[32] Günther S, Emmerich P, Laue T, Kühle O, Asper M, Jung A, et al. Imported Lassa fever in Germany: molecular characterization of a new Lassa virus strain. Emerg Infect Dis 2000; 6:466-76.

[33] Jones J. Lassa fever imported to England. Euro Surveill 2000;4(11):pii=1639. 
http://www.eurosurveillance.org/ViewArticle.aspx?Articleld=1639 [accessed 27 Mar 2010].

Crowcroft NS, Meltzer M, Evans M, Shetty N, Maguire H, Bahl M, et al. The public health response to a case of Lassa fever in London in 2000 . J Infect 2004;48:221-8.

Schmitz H, Kohler B, Lane T, Drosten C, Veldkamp PJ, Gunther S, et al. Monitoring of clinical and laboratory data in two cases of imported Lassa fever. Microbes Infect 2002;4:43-50.

[36] Veldkamp PJ, Schippers EF. A man with fatal Lassa fever following a stay in Sierra Leone[in Dutch]. Ned Tijdschr Geneeskd 2002;146:2201-4.

[37] Public Health Laboratory Service Communicable Disease Surveillance Centre. Case of Lassa fever in a soldier returning to the United Kingdom. Commun Dis Rep CDR Wkly 2003;13:1-2.

[38] Centers for Disease Control and Prevention. Imported Lassa feverNew Jersey, 2004. MMWR Morb Mortal Wkly Rep 2004; 53: 894-7.

[39] Unit for Surveillance and Communication, Unit for Preparedness and Response, Editorial team. E-alert 24 July: Case of Lassa fever imported into Germany from Sierra Leone. Euro Surveill 2006;11(30):pii=3008. http://www.eurosurveillance.org/ViewArticle.aspx?Articleld=3008 [accessed 27 Mar 2010].

[40] ProMED-mail. Lassa fever - South Africa ex Nigeria. ProMED-mail 2007; 22 Feb: 20070222.0657. http://www.promedmail.org [accessed 27 Mar 2010]. 
Kitching A, Addiman S, Cathcart S, Bishop L, Krahé D, Nicholas M, et al. A fatal case of Lassa fever in London, January 2009. Euro Surveill 2009;14(6):pii=19117.

http://www.eurosurveillance.org/ViewArticle.aspx?Articleld=19117 [accessed 27 Mar 2010].

[42] Atkin S, Anaraki S, Gothard P, Walsh A, Brown D, Gopal R, et al. The first case of Lassa fever imported from Mali to the United Kingdom, February 2009. Euro Surveill 2009;14(10):pii=19145.

http://www.eurosurveillance.org/ViewArticle.aspx?Articleld=19145 [accessed 27 Mar 2010].

[43] Paweska J, Sewlall NH, Hsiazek TG, Blumberg LH, Hale MJ, Lipkin WI, et al. Nosocomial outbreak of novel arenavirus infection, Southern Africa. Emerg Infect Dis 2009;15:1598-602.

[44] Gear JS, Cassel GA, Gear AJ, Trappler B, Clausen L, Meyers AM, et al. Outbreak of Marburg virus disease in Johannesburg. $\mathrm{Br}$ Med $\mathrm{J}$ 1975;4:489-93.

[45] Smith DH, Johnson BK, Isaacson M, Swanepoel R, Johnson KM, Killey M, et al. Marburg-virus disease in Kenya. Lancet 1982;1:816-20. WHO. Marburg haemorrhagic fever: factsheet. Geneva: World Health Organization; 2008.

http://www.who.int/mediacentre/factsheets/fs_marburg/en/index.html [accessed 27 Mar 2010]. 
Timen A, Koopmans MPG, Vossen ACTM, van Doornum GJJ, Günther

S, van den Berkmortel F, et al. Response to imported case of Marburg hemorrhagic fever, the Netherlands. Emerg Infect Dis 2009;15;1171-5.

[48] Centers for Disease Control and Prevention. Special Pathogens Branch. Outbreak Posting. 2008: Marburg hemorrhagic fever, imported case United States. http://cdc.gov/ncidod/dvrd/spb/outbreaks/index.htm [accessed 21 Dec 2009].

[49] Kenyon RH, Niklasson B, Jahrling PB, Geisbert T, Svensson L, Frydén A, et al. Virologic investigation of a case of suspected haemorrhagic fever. Res Virol 1994;145:397-406.

[50] Formenty P, Hatz C, Guenno BL, Stoll A, Rogenmoser P, Widmer A. Human infection due to Ebola virus, subtype Côte d'Ivoire: clinical and biologic presentation. J Infect Dis 1999;179(Suppl 1):S48-53.

[51] World Health Organization. Ebola haemorrhagic fever. Wkly Epidemiol $\operatorname{Rec} 1996 ; 71: 359$.

[52] Swanepoel R, Shepherd AJ, Leman PA, Shepherd SP, McGillivray GM, Erasmus MJ, et al. Epidemiological and clinical features of CrimeanCongo fever in southern Africa. Am J Trop Med Hyg 1987;36:120-32. Stuart J. Suspected case of Crimean/Congo haemorrhagic fever in British traveller returning from Zimbabwe. Euro Surveill 1998;2(8):pii=1256. http://www.eurosurveillance.org/ViewArticle.aspx?Articleld=1256 [accessed 27 Mar 2010].

[54] European Network for Diagnostics of "Imported" Viral Diseases (ENIVD). Overview. http://www.enivd.de/over.htm [accessed 27 Mar 2010]. 
Jauréguiberry $S$, Tattevin $\mathrm{P}$, Tarantola A, Legay F, Tall A, Nabeth $\mathrm{P}$, et al. Imported Crimean-Congo hemorrhagic fever. J Clin Microbiol 2005:43: $4905-7$.

[56] Tarantola A, Nabeth P, Tattevin P, Michelet C, Zeller H, Incident Management Group. Look back exercise with imported Crimean-Congo hemorrhagic fever, Senegal and France. Emerg Infect Dis 2006;12:1424-6.

[57] ProMED-mail. Crimean-Congo hemorrhagic fever, fatal - Germany ex Afghanistan. ProMED-mail 2009; 19 Sept: 20090919.3286. http://www.promedmail.org [accessed 27 Mar 2010].

Mahdy MS, Bansen E, Joshua JM, et al. Potential importation of dangerous exotic arbovirus diseases. A case report of Rift Valley fever with retinopathy. Can Dis Wkly Rep 1979;5:189-91.

$$
\text { Niklasson B, Meegan JM, Bengtsson E. Antibodies to Rift Valley fever }
$$
in Swedish U.N. soldiers in Egypt and the Sinai. Scand J Infect Dis $1979 ; 11: 313-4$.

[60] Deutman AF, Klomp HJ. Rift Valley fever retinitis. Am J Ophthalmol 1981;92:38-42.

[61] Durand JP, Bouloy M, Richecoeur L, Peyrefitte CN, Tolou H. Rift Valley fever virus infection among French troops in Chad. Emerg Infect Dis 2003;9:751-2. $\mathrm{T}$, et al. Fatal outcome of hepatitis A virus (HAV) infection in a traveler with incomplete HAV vaccination and evidence of Rift Valley fever virus infection. J Clin Microbiol 2008;46:3850-2. 
Pon E, McKee KT Jr, Diniega BM, Merrell B, Corwin A, Ksiazek TG.

Outbreak of hemorrhagic fever with renal syndrome among US marines in Korea. Am J Trop Med Hyg 1990;42:612-19.

[64] France AJ, Burns SM. Hantavirus infection: a new imported viral haemorrhagic fever. J Infect 1988;16:108-9.

Bateman W, Clement J, Solano K, Vanherwegem JL, van der Groen G. Hemorrhagic fever with renal syndrome in a Canadian serviceman. CMAJ $1990 ; 143: 38-40$.

[66] Bruno P, Hassell LH, Quan J, Brown J. Hemorrhagic fever with renal syndrome imported to Hawaii from West Germany. Am J Med 1990;89:232-4.

[67] Clement J, Underwood P, Ward D, Pilaski J, LeDuc J. Hantavirus outbreak during military manoeuvres in Germany. Lancet 1996;347:336.

[68] Moulin B, Olmer M, Simonetti SD, Ferrero A, Paix MA, Rollin PE, et al. A case of imported hemorrhagic fever with renal syndrome [in French]. Presse Med 1991;20:2162.

[69] Clement J, McKenna P, Avsic-Zupanc T, Skinner CR. Rat-transmitted hantavirus in Sarajevo. Lancet 1994;344:131.

[70] Stuart LM, Rice PS, Lloyd G, Beale RJ. A soldier in respiratory distress. Lancet 1996;347:30.

[71] Pejcoch M, Petrů K, Monhart V, Matyásová J. An imported case of hemorrhagic fever with renal syndrome[in Czech]. Epidemiol Mikrobiol Immunol 1996;45:127-9. 
Lui JW, Lee BJ, Ko WC, Chuang YC. Hemorrhagic fever with renal syndrome: first imported case of hantavirus infection in Taiwan. J Formos Med Assoc 1996;95:480-3.

[73] Sanchez JL Jr, Craig SC, Kohlhase K, Polyak C, Ludwig SL, Rumm PD. Health assessment of US military personnel deployed to BosniaHerzegovina for operation joint endeavour. Mil Med 2001; 166:470-4.

[74] Keyaerts E, Ghijsels E, Lemey P, Maes P, Zachée P, Daelmans R, et al. Plasma exchange-associated immunoglobulin m-negative hantavirus disease after a camping holiday in southern France. Clin Infect Dis 2004;38:1350-6.

[75] Caramello P, Canta F, Bonino L, Moiraghi C, Navone F, Lipani F, et al. Puumala virus pulmonary syndrome in a Romanian immigrant. J Travel Med $2002 ; 9: 326-9$.

[76] Lledó L, Gegúndez MI, Martinez JC, Sanfeliu. Epidemic nephropathy in Spain: first imported case [in Spanish]. Med Clin (Barc) 2003;121:677.

[77] Puljiz I, Kuzman I, Markotić A. Imported case of nephropathia epidemica - a case report. Coll Anthropol 2008;32:1263-5.

[78] Song J-W, Moon S-S, Gu SH, Song K-J, Baek LJ, Kim HC, et al. Hemorrhagic fever with renal syndrome in 4 US soldiers, South Korea, 2005. Emerg Infect Dis 2009;15:1833-6.

[79] Schmidt-Chansit J, Meisel H, Hofmann J, Rang A, Lambrecht E, Ulrich RG, et al. Clinical course and laboratory parameters of the first DobravaBelgrade hantavirus infection imported to Germany. J Clin Virol 2008; 42:913. 
Demeester R, Bottieau E, van Esbroek M, Pourkarim MR, Maes P, Clement J. Hantavirus nephropathy as a pseudo-import from Ecuador. Eur J Clin Microbiol Infect Dis 2010;29:59-62.

$$
\text { Espinoza R, Vial P, Noriega LM, Johnson A, Nichol SL, Rollin PE, et al. }
$$

Hantavirus pulmonary syndrome in a Chilean patient with recent travel in Bolivia. Emerg Infect Dis 1998;4:93-5.

[82] Murgue B, Domart Y, Coudrier D, Rollin PE, Darchis JP, Merrien D, et al. First reported case of imported Hantavirus pulmonary syndrome in Europe. Emerg Infect Dis 2002;8:106-7.

[83] Reynolds S, Galanis E, Krajden M, Morshed M, Bowering D, Abelson W, et al. Imported fatal Hantavirus pulmonary syndrome. Emerg Infect Dis 2007;13:1424-5.

[84] Towner JS, Amman BR, Sealy TK, Carroll SA, Comer JA, Kemp A, et al. Isolation of genetically diverse Marburg viruses from Egyptian fruit bats. PLoS Pathog 2009; 5:e1000536.

Swanepoel R, Smit SB, Rollin PE, Formenty P, Leman PA, Kemp A, et al. Studies of reservoir hosts for Marburg virus. Emerg Infect Dis 2007;13:1847-51.

$$
\text { Leroy EM, Epelboin A, Mondonge V, Pourrut X, Gonzalez JP, }
$$

Mugumbe-Tamfum JJ, et al. Human Ebola outbreak resulting from direct exposure to fruit bats in Luebo, Democratic Republic of Congo, 2007. Vector Borne Zoonotic Dis 2009; 9:723-8.

[87] Monath TP, Cetron MS. Prevention of yellow fever in persons traveling to the tropics. Clin Infect Dis 2002;34:1369-78. 
Digoutte JP, Plessart H, Salaun JJ, Heme G, Ferrara L, Germain M. A propos de trois cas de fièvre jaune contractée au Sénégal. Bull World Health Organ 1981;59:759-66.

[89] World Health Organization. Yellow fever. Wkly Epidemiol Rec 1986;61:59-60 and 61:380.

[90] Nolla-Salas J, Sadalls-Radresa J. Imported yellow fever in vaccinated tourist. Lancet 1989;2:1275.

[91] Barros ML, Boecken G. Jungle yellow fever in the central Amazon. Lancet 1996;348:969-70.

[92] World Health Organization. Yellow fever. Wkly Epidemiol Rec 1998;73:354-9.

[93] McFarland J, Baddour LM, Nelson JE, Elkins SK, Craven RB, Cropp BC, et al. Imported yellow fever in a United States citizen. Clin Infect Dis $1997 ; 25: 1143-7$.

[94] Teichmann D, Grobusch MP, Wesselmann H, Temmesfeld-Wollbrück B, Breuer T, Dietel M, et al. A haemorrhagic fever from the Côte d'Ivoire. Lancet 1999;354:1608.

[95] Centers for Disease Control and Prevention. Fatal yellow fever in a traveler returning from Venezuela, 1999. MMWR Morb Mortal Wkly Rep 2000;49:303-5.

[96] Colebunders R. Imported case of confirmed yellow fever detected in Belgium. Euro Surveill 2001;5(47):pii=2058 http://www.eurosurveillance.org/ViewArticle.aspx?Articleld=2058 [accessed 27 Mar 2010]. 
[97] Centers for Disease Control and Prevention. Fatal yellow fever in a traveler returning from Amazonas, Brazil, 2002. MMWR Morb Mortal Wkly Rep 2002;51:324-5.

[98] Burney MI, Ghafoor A, Saleem M, Webb PA, Casals J. Nosocomial outbreak of a viral hemorrhagic fever caused by Crimean hemorrhagic feverCongo virus in Pakistan, January 1976. Am J Trop Med Hyg 1980;29:941-7.

[99] Khan AS, Maupin GO, Rollin PE, Noor AM, Shurie HH, Shalabi AG, et al. An outbreak of Crimean-Congo hemorrhagic fever in the United Arab Emirates, 1994-1995. Am J Trop Med Hyg 1997;57:519-25.

[100] El-Azazy OME, Scrimgeour EM. Crimean-Congo haemorrhagic fever virus infection in the Western Province of Saudi Arabia. Trans R Soc Trop Med Hyg 1997;91:275-8.

[101] Balkhy HH, Memish ZA. Rift Valley fever: an uninvited zoonosis in the Arabian peninsula. Int J Antimicrob Agents 2003;21:153-7.

[102] Madani TA. Alkhumra virus infection, a new viral haemorrhagic fever in Saudi Arabia. J Infect 2005;51:91-7.

[103] Martini GA. Marburg virus disease. Postgrad Med J 1973;49:542-6.

[104] Jahrling PB, Geisbert TW, Dalgard DW, Johnson ED, Ksiazek TG, Hall WC, et al. Preliminary report: isolation of Ebola virus from monkeys imported to USA. Lancet 1990;335:502-5.

[105] Barrette RW, Metwally SA, Rowland JM, Xu L, Zaki SR, Nichol ST, et al. Discovery of swine as a host for the Reston Ebolavirus. Science 2009;325:204-6. 
[106] Lloyd G, Jones N. Infection of laboratory workers with hantavirus acquired from immunocytomas propagated in laboratory rats. J Infect 1986;12:117-25.

[107] WHO. International Health Regulations (2005). Geneva: World Health Organization; 2008. http://www.who.int/ihr/9789241596664/en/index.html [accessed 28 April 2010].

[108] Ergönül O, Celikbaş A, Dokuzoğuz B, Eren S, Baykam N, Esener H. Ribavirin in Crimean-Congo hemorrhagic fever: primum non nocere. Clin Infect Dis 2009;49:1621-2.

[109] Wilson ME, Weld LH, Boggild A, Keystone JS, Kain KC, von Sonnenburg F, et al. Fever in returned travelers: results from the GeoSentinel Surveillance Network. Clin Infect Dis 2007;44:1560-8.

[110] Tilzey AI, Webster M, Banatvala JE. Patients with suspected Lassa fever in London during 1984: problems in their management at St Thomas's Hospital. Br Med J 1984:291:1554-5.

[111] Woodrow CJ, Eziefula AC, Agranoff D, Scott GM, Watson J, Chiodini PL, et al. Early risk assessment for viral haemorrhagic fever: experience at the Hospital for Tropical Diseases, London, UK. J Infect 2007;54:6-11.

[112] Health Protection Agency. Malaria: epidemiological data. http://www.hpa.org.uk/HPA/Topics/InfectiousDiseases/InfectionsAZ/11919421 28262/ [accessed 27 Mar 2010].

[113] Health Protection Agency. Laboratory reports of enteric fever confirmed by the Laboratory of Gastrointestinal Pathogens at the Health Protection Agency Centre for Infections and supplied by the Travel and Migrant Health 
Section, Centre for Infections (personal communication, Jo Lawrence, 26 Mar 2010).

[114] Advisory Committee on Dangerous Pathogens. Management and control of viral haemorrhagic fevers. London: The Stationery Office; 1996.

[115] Anathallee M, Curphey A, Beeching N, Carley S, Crawford I, MackwayJones K. Emergency departments (EDs) in the United Kingdom (UK) are not prepared for emerging biological threats and bioterrorism. J Infect $2007 ; 54: 12-7$.

[116] Lalloo DG, Shingadia D, Pasvol G, Chiodini PL, Whitty CJ, Beeching NJ, et al. UK malaria treatment guidelines. J Infect 2007;54:111-21.

[117] Griffith KS, Lewis LS, Mali S, Parise ME. Treatment of malaria in the United States. A systematic review. JAMA 2007;297:2264-77.

[118] Haas WH, Breuer T, Pfaff G, Schmitz H, Köhler P, Asper M, et al. Imported Lassa fever in Germany: surveillance and management of contact persons. Clin Infect Dis 2003;36:1254-8.

[119] Tarantola A, Ergonul O, Tattevin P. Estimates and prevention of Crimean-Congo hemorrhagic fever risks for health care workers. In: Ergönul O, Whitehouse CA, editors. Crimean-Congo hemorrhagic fever - a global perspective. Dordrecht, Netherlands: Springer; 2007, pp. 281-94.

[120] Isaäcson M. Viral hemorrhagic fever hazards for travelers in Africa. Clin Infect Dis 2001;33:1707-12.

[121] Fisher-Hoch SP. Lessons from nosocomial viral haemorrhagic fever outbreaks. Br Med Bull 2005;73-74:123-37. DOI: 10.1093/bmb/ldh054. 
[122] Ferres M, Vial P, Marc C, Yanez L, Godoy P, Cartillo C, et al.

Prospective evaluation of household contacts of persons with hantavirus cardiopulmonary syndrome in Chile. J Infect Dis 2007;195: 1563-71.

[123] Lindsey NP, Schroeder BA, Miller ER, Braun MM, Hinckley AF, Marano $\mathrm{N}$, et al. Adverse event reports following yellow fever vaccination. Vaccine 2008;26: 6077-82. 
Table 1

Epidemiological features of viral haemorrhagic fevers (VHF) reported in travellers 1969-2009

\begin{tabular}{|c|c|c|c|c|c|}
\hline $\begin{array}{l}\text { Virus family } \\
\text { VHF }\end{array}$ & Reservoir & Transmission & Main risk areas & $\begin{array}{l}\text { Main traveller } \\
\text { populations at risk }\end{array}$ & $\begin{array}{l}\text { Incubation } \\
\text { period } \\
\text { (days) }\end{array}$ \\
\hline
\end{tabular}

Arenaviridae

Lassa fever

Rodents

Infected rodent contact

West Africa

Missionaries and Inhaled aerosol rodent aid workers

urine

Ingested rodent excreta

Rodent excreta on

broken skin

Healthcare and

laboratory

Lujo

Unknown

Unknown

Healthcare

Sub-Saharan Africa

Unknown

$7-13^{a}$

Rural travellers

Military

Filoviridae

Marburg

\section{Uncertain \\ probable secondary \\ host}

Bats, caves and mines

Healthcare

Other primates Laboratory

Healthcare workers

Ebola

$\begin{array}{ll}\text { Uncertain } & \text { Healthcare } \\ \text { Fruit bats } & \text { Laboratory }\end{array}$

Bunyaviridae

Crimean-

Congo

Livestock (cattle,

haemorrhagic

sheep, etc.)

fever

Tick (Hyalomma) bites

Crushing ticks

Contact with blood/fluids

of infected animals

Healthcare
Sub-Saharan Africa

Sub-Saharan Africa

Healthcare workers

$3-16$

Zoologists

Miners and tourists

in caves

Healthcare workers

$3-16$

Africa, former

Soviet Union, South

Rural travel

and East Europe,

Middle East,

Eurasia, western
Aid workers

Military 
Rift Valley Livestock

fever

Mosquito bites (Aedes)

Contact with blood/fluids

of infected animals

Unpasteurized milk

Needlestick and

laboratory

Haemorrhagic Rodents (striped field

fever with

renal

mice, yellow-necked mice, rats, or bank

syndrome

(HFRS)

Hantavirus

pulmonary

syndrome

Flaviviridae

Yellow fever

\begin{abstract}
Monkeys
Humans in urban cycles
\end{abstract} excreta, saliva and from contaminated dust, nesting materials etc. Laboratory excreta, saliva etc., as HFRS

Laboratory

\section{Mosquito bites (Aedes,} also in Americas Haemagogus)

\section{Sub-Saharan}

Africa, Middle East

Military on rural

postings

Aerosols of rodent urine, Worldwide, but

Aerosols of rodent urine, North and South

mainly in East Asia and Europe

Campers, hikers

etc.

Military

Hikers, farm visitors

$7-28$

America

etc.

Needlestick and laboratory
West, sub-Saharan and East Africa

Rural travellers

Central and South

America

\footnotetext{
a Based on few cases only.
} 


\section{Table 2}

Lassa fever in travellers, 1969-2009a






$\begin{array}{lllllllll}1975 & \text { Sierra Leone } & \text { USA } & 39 & \text { F } & \text { Aid Worker } & \text { No } & \text { [21] } \\ 1975 & \text { Nigeria } & \text { UK } & 39 & \text { M } & \text { Physician } & \text { Yes } & \text { Death day } 8 & \text { [20,22] } \\ 1976 & \text { Nigeria } & \text { UK } & \text { NS } & \text { M } & \text { Engineer } & \text { No } & \text { [22] } \\ 1976 & \text { Sierra Leone } & \text { USA } & 43 & \text { F } & \text { Aid Worker } & \text { No } & \text { [21] } \\ 1980 & \text { Burkina Faso } & \text { Netherlands } & 34 & \text { M } & \text { Aid Worker } & \text { No } & \text { [24] } \\ 1981 & \text { Nigeria } & \text { UK } & 18 & \text { F } & \text { Teacher } & \text { No } & \text { [25] } \\ 1982 & \text { Nigeria } & \text { UK } & 21 & \text { F } & \text { Diplomat } & \text { No } & \text { [26] } \\ 1984 & \text { Sierra Leone } & \text { UK } & \text { NS } & \text { M } & \text { Geologist } & \text { No } & \text { [27] } \\ 1985 & \text { Sierra Leone } & \text { UK } & 27 & F & \text { Nurse } & \text { No }\end{array}$









\begin{tabular}{|c|c|c|c|c|c|c|c|c|}
\hline 2003 & Sierra Leone & UK & NS & M & Soldier & No & & [37] \\
\hline 2004 & $\begin{array}{l}\text { Sierra Leone, } \\
\text { Liberia }\end{array}$ & USA & 38 & $M$ & $\begin{array}{l}\text { Businessm } \\
\text { an }\end{array}$ & Yes & Death $\sim$ day 7 & [38] \\
\hline 2006 & Sierra Leone & Germany & 68 & $M$ & Tourist & No & & [39] \\
\hline 2007 & Nigeria & S. Africa & 46 & $M$ & Physician & No & $\begin{array}{l}\text { Re-reported in } \\
2009\end{array}$ & {$[40]$} \\
\hline 2009 & Nigeria & UK & 66 & $M$ & Retired & Yes & Death day 23 & {$[41]$} \\
\hline 2009 & Mali & UK & $20 \mathrm{~s}$ & $M$ & Working & Yes & Death day 11 & {$[42]$} \\
\hline
\end{tabular}

a Updated after Macher and Wolfe 2006 [16].

NS, not stated. 


\section{Table 3}

Viral haemorrhagic fevers in travellers, 1969-2009, excluding Lassa and yellow fever

\begin{tabular}{|c|c|c|c|c|c|c|c|c|}
\hline Agent & Year & $\begin{array}{l}\text { Country of } \\
\text { origin }\end{array}$ & Imported to & $\begin{array}{l}\text { Age } \\
\text { (years) }\end{array}$ & Gender & Fatal & Comments & Ref \\
\hline \multicolumn{9}{|c|}{ Arenaviruses } \\
\hline Lujo & 2008 & Zambia & S. Africa & 36 & $\mathrm{~F}$ & Yes & $\begin{array}{l}\text { Safari agent } \\
\text { Four secondary cases in HCW, } \\
\text { of whom three died (one } \\
\text { below) }\end{array}$ & [43] \\
\hline Lujo & 2008 & Zambia & S. Africa & 33 & $M$ & Yes & $\begin{array}{l}\text { Paramedic who assisted } \\
\text { patient above }\end{array}$ & [43] \\
\hline \multicolumn{9}{|c|}{ Filoviruses } \\
\hline Marburg & 1975 & Zimbabwe & S. Africa & 20 & M & Yes & $\begin{array}{l}\text { Australian tourist - secondary } \\
\text { cases in girlfriend and nurse, } \\
\text { both survived }\end{array}$ & [44] \\
\hline Marburg & 1980 & $\begin{array}{l}\text { Kenya - Kitum } \\
\text { Cave }\end{array}$ & $\begin{array}{l}\text { Kenya - } \\
\text { Nairobi }\end{array}$ & 56 & M & Yes & $\begin{array}{l}\text { French engineer } \\
\text { Secondary case (physician) } \\
\text { survived }\end{array}$ & [45] \\
\hline Marburg & 1987 & $\begin{array}{l}\text { Kenya - Kitum } \\
\text { Cave }\end{array}$ & Kenya & 15 & $M$ & Yes & Danish tourist, extensive travel & [46] \\
\hline Marburg & 2008 & $\begin{array}{l}\text { Uganda - } \\
\text { Python Cave }\end{array}$ & Netherlands & 41 & $\mathrm{~F}$ & Yes & $\begin{array}{l}\text { Tourist, visited Python Cave, } \\
\text { Maramagambo Forest }\end{array}$ & [47] \\
\hline
\end{tabular}




\begin{tabular}{|c|c|c|c|c|c|c|c|c|}
\hline & & & & & & & $\begin{array}{l}130 \text { contacts, no } \\
\text { seroconversions/illness }\end{array}$ & \\
\hline Marburg & 2008 & $\begin{array}{l}\text { Uganda - } \\
\text { Python Cave }\end{array}$ & USA & 44 & & No & $\begin{array}{l}\text { Tourist, visited Python Cave } \\
\text { and diagnosed retrospectively } \\
\text { No illness in } \sim 260 \text { contacts } \\
(220 \mathrm{HCW})\end{array}$ & [48] \\
\hline $\begin{array}{l}\text { Unknown } \\
\text { filovirus }\end{array}$ & 1990 & Kenya & Sweden & 21 & M & No & $\begin{array}{l}\text { Tourist - typical filovirus } \\
\text { features but virus not } \\
\text { confirmed }\end{array}$ & [49] \\
\hline Ebola & 1994 & Côte d'Ivoire & Switzerland & 34 & $\mathrm{~F}$ & No & $\begin{array}{l}\text { Scientist who did chimpanzee } \\
\text { autopsy } \\
\text { No seroconversions in } 74 \\
\text { contacts }\end{array}$ & [48] \\
\hline Ebola & 1996 & Gabon & S. Africa & NS & M & No & $\begin{array}{l}\text { Physician - secondary case in } \\
\text { nurse, who died }\end{array}$ & [51] \\
\hline \multicolumn{9}{|c|}{ Bunyaviruses } \\
\hline $\mathrm{CCHF}$ & 1985 & Zaire (DRC) & S. Africa & 48 & M & Yes & Cattle-farm exposure & [52] \\
\hline $\mathrm{CCHF}$ & 1986 & Tanzania & S. Africa & 26 & M & No & Possible tick bites & [52] \\
\hline $\mathrm{CCHF}$ & 1997 & Zimbabwe & UK & 78 & $\mathrm{~F}$ & Yes & $\begin{array}{l}\text { Tourist to farm near Harare } \\
\text { No illness among } 60 \text { contacts }\end{array}$ & [53] \\
\hline $\mathrm{CCHF}$ & 2001 & Bulgaria & Germany & NS & NS & No & Tourist & [54] \\
\hline $\mathrm{CCHF}$ & 2004 & Senegal & France & 60 & $\mathrm{~F}$ & No & Medical technician & {$[55,5$} \\
\hline
\end{tabular}




\begin{tabular}{|c|c|c|c|c|c|c|c|}
\hline $\mathrm{CCHF}$ & 2009 & Afghanistan & Germany & 22 & M & Yes & US soldier \\
\hline RVF & 1979 & Kenya & $\begin{array}{l}\text { Saudi } \\
\text { Arabia, } \\
\text { Canada }\end{array}$ & 41 & $\mathrm{~F}$ & No & $\begin{array}{l}\text { Canadian expatriate, diagnosis } \\
\text { in Saudi Arabia, ophthalmology } \\
\text { reviews in Canada }\end{array}$ \\
\hline RVF & 1979 & Egypt & Sweden & NA & NS & No & $\begin{array}{l}\text { Eight soldiers, fever } \\
\text { serosurveillance }\end{array}$ \\
\hline RVF & 1981 & Tanzania & Netherlands & 57 & $\mathrm{~F}$ & No & Expatriate, for ophthalmic care \\
\hline RVF & 2001 & Chad & France & NA & M & No & $\begin{array}{l}\text { Two symptomatic soldiers, } \\
\text { fever serosurveillance }\end{array}$ \\
\hline RVF & 2008 & Kenya & Germany & 71 & $\mathrm{~F}$ & Yes & $\begin{array}{l}\text { Tourist with fatal hepatitis A } \\
\text { and probable RVF }\end{array}$ \\
\hline HFRS & 1986 & S. Kor & [USA] & NA & M & Yes & $\begin{array}{l}\text { Of } 14 \text { symptomatic US soldiers } \\
10 \text { were hospitalized with } 2 \\
\text { deaths }\end{array}$ \\
\hline HFRS & 1987 & Malaysia & UK & 47 & $M$ & No & $\begin{array}{l}\text { Businessman with Far East } \\
\text { strain }\end{array}$ \\
\hline HFRS & 1988 & Belgium & [Canada] & 46 & M & No & $\begin{array}{l}\text { Canadian soldier living next to } \\
\text { forest }\end{array}$ \\
\hline HFRS & 1988 & Germany & USA & 24 & M & No & $\begin{array}{l}\text { Soldier } \\
\text { Puumala virus }\end{array}$ \\
\hline
\end{tabular}




\begin{tabular}{|c|c|c|c|c|c|c|c|}
\hline HFRS & 1990 & Germany & [USA] & NA & M & No & $\begin{array}{l}\text { US military exercise outbreak; } \\
16 / 23 \text { cases symptomatic } \\
\text { Puumala virus }\end{array}$ \\
\hline HFRS & 1991 & Romania & France & NS & $M$ & No & $\begin{array}{l}\text { Working with laboratory rats } \\
\text { Seoul or similar virus }\end{array}$ \\
\hline HFRS & 1992 & Bosnia & Croatia & 24 & M & No & $\begin{array}{l}\text { Canadian UN worker } \\
\text { Seoul virus }\end{array}$ \\
\hline HFRS & 1995 & Bosnia & UK & 19 & M & No & $\begin{array}{l}\text { Soldier with severe respiratory } \\
\text { and renal disease } \\
\text { Seoul virus }\end{array}$ \\
\hline HFRS & 1995 & Croatia & $\begin{array}{l}\text { Czechoslova } \\
\text { kia }\end{array}$ & 28 & $M$ & No & $\begin{array}{l}\text { Soldier with severe disease } \\
\text { requiring dialysis } \\
\text { Strain uncertain }\end{array}$ \\
\hline HFRS & 1996 & China & Taiwan & 38 & $M$ & No & $\begin{array}{l}\text { Led to finding hantaviruses in } \\
\text { Taiwan }\end{array}$ \\
\hline HFRS & 1996 & Bosnia & USA & NA & $M$ & No & $\begin{array}{l}\text { Two soldiers - one } \\
\text { symptomatic, one found on } \\
\text { serosurveillance }\end{array}$ \\
\hline HFRS & 1999 & France & Belgium & 37 & $M$ & No & $\begin{array}{l}\text { Camping } \\
\text { Puumala virus with HPS }\end{array}$ \\
\hline HFRS & 2002 & $\begin{array}{l}\text { Romania, } \\
\text { Balkan } \\
\text { countries, NS }\end{array}$ & Italy & NS & $M$ & No & $\begin{array}{l}\text { 'Young man' } \\
\text { Puumala virus with HPS }\end{array}$ \\
\hline
\end{tabular}




\begin{tabular}{|c|c|c|c|c|c|c|c|c|}
\hline HFRS & 2003 & $\begin{array}{l}\text { Central Europe, } \\
\text { NS }\end{array}$ & Spain & 32 & $M$ & No & $\begin{array}{l}\text { Trucker } \\
\text { Puumala virus }\end{array}$ & [76] \\
\hline HFRS & 2005 & Sweden & Croatia & 41 & $M$ & No & $\begin{array}{l}\text { Holiday home in forest } \\
\text { Puumala virus }\end{array}$ & [77] \\
\hline HFRS & 2005 & S. Korea & [USA] & NA & $M$ & No & $\begin{array}{l}\text { Four symptomatic soldiers in } \\
\text { rural areas }\end{array}$ & [78] \\
\hline HFRS & 2006 & Serbia & Germany & 65 & M & No & $\begin{array}{l}\text { Rural holiday home } \\
\text { Dobrava virus }\end{array}$ & [79] \\
\hline HFRS & 2009 & $\begin{array}{l}\text { (Ecuador) } \\
\text { Belgium }\end{array}$ & Belgium & 22 & $\mathrm{~F}$ & No & $\begin{array}{l}\text { Pseudo-importation of } \\
\text { Puumala virus acquired on } \\
\text { return to Belgium }\end{array}$ & [80] \\
\hline HPS & 1997 & Bolivia & Chile & 20 & M & Yes & $\begin{array}{l}\text { Backpacking, rural } \\
\text { Laguna Negra virus }\end{array}$ & [81] \\
\hline HPS & 2001 & Chile, Argentina & France & 58 & M & No & $\begin{array}{l}\text { Botanist in rural Chile and } \\
\text { Argentina } \\
\text { Virus not isolated, serology } \\
\text { only }\end{array}$ & [82] \\
\hline HPS & 2006 & Bolivia & Canada & 15 & $F$ & Yes & $\begin{array}{l}\text { Tourist on farms with rodent } \\
\text { droppings } \\
\text { Andes virus }\end{array}$ & [83] \\
\hline
\end{tabular}

CCHF, Crimean-Congo haemorrhagic fever; DRC, Democratic Republic of Congo; HCW, healthcare worker; HFRS, haemorrhagic fever with renal syndrome (hantavirus); HPS, hantavirus pulmonary syndrome; NA, not applicable; NS, not stated; RVF, Rift Valley fever. 


\section{Table 4}

Yellow fever in travellers, 1970-2009ª

\begin{tabular}{|c|c|c|c|c|c|c|c|c|}
\hline Year & Country of infection & Imported to & Age & Gender & Profession & Fatal & Vaccinated & Ref. \\
\hline 1979 & Senegal & France & 42 & M & Tourist & Yes & No & [88] \\
\hline 1979 & Senegal & France & 25 & $\mathrm{M}$ & Tourist & Yes & No & {$[88]$} \\
\hline 1985 & $\begin{array}{l}\text { Guinea-Bissau, The } \\
\text { Gambia, Senegal }\end{array}$ & Netherlands & 27 & $\mathrm{~F}$ & Tourist & No & No & [89] \\
\hline 1987 & Niger, Mali, Burkina & Spain & 37 & $\mathrm{~F}$ & Tourist & No & Yes & {$[90]$} \\
\hline 1996 & Brazil & Switzerland & 53 & $M$ & Tourist & Yes & No & {$[91,92]$} \\
\hline
\end{tabular}




$\begin{array}{lllllllll}1997 & \text { Brazil } & \text { USA } & 45 & \text { M } & \text { Tourist } & \text { Yes } & \text { No } & \text { [93] } \\ 1999 & \text { Côte d'Ivoire } & \text { Germany } & 39 & \text { M } & \text { Cameraman } & \text { Yes } & \text { No } & {[94]} \\ 1999 & \text { Venezuela } & \text { USA } & 48 & \text { M } & \text { Tourist } & \text { Yes } & \text { No } & {[95]} \\ 2001 & \text { The Gambia } & \text { Belgium } & 47 & \text { F } & \text { Tourist } & \text { Yes } & \text { No } & \text { [96] } \\ 2002 & \text { Brazil } & \text { USA } & 47 & \text { M } & \text { Tourist } & \text { Yes } & \text { No } & \text { [97] }\end{array}$

${ }^{a}$ updated after Monath and Cetron 2002 [87]. 